\title{
Decoding Protein-Protein Interactions through Combinatorial Chemistry: Sequence Specificity of SHP-1, SHP-2, and SHIP SH2 Domains
}

\author{
(Supporting Information)
}

\author{
Michael C. Sweeney, Anne-Sophie Wavreille, Junguk Park, Jonathan P. Butchar, \\ Susheela Tridandapani, and Dehua Pei*
}

Table S1: Additional peptides that bind to the C-SH2 domain of SHP-2. They were derived from a screening performed at $50 \mathrm{nM}$ SHP-2 C-SH2 domain. The sequences in boldfaced letters represent peptides derived from intensely colored beads (total 90), whereas the rest were from less colored beads (total $\sim 150$ ).

Table S2: Additional peptide sequences that bind to the N-SH2 domain of SHP-2. These sequences were derived from lightly colored beads from three different screening experiments conducted at 10 and $50 \mathrm{nM} \mathrm{N-SH} 2$ protein.

Table S3: Additional peptide sequences that bind to SHIP SH2 domain, derived from lightly colored beads.

Table S4. Additional proteins that are know to interact with SHP-1 and/or SHP-2 via SHP-1/2 SH2 domains and pY motifs. These proteins did not turn up in the database search using the tandem consensus motifs because they contain only one ITIM-like motif, have non-optimal amino acids at critical positions in one or both ITIM motifs, or bind SHP-1/2 via a non-classical ITIM motif, (V/I/L)XpY(M/L/F)XP. ${ }^{\text {p}}$ proteins that interact with SHP-1; ${ }^{b}$ proteins that interact with SHP-2; ${ }^{c}$ proteins that interact with SHIP.

Figure S1: Specificity of SHP-2 N-SH2 domain. The four classes of N-SH2 domainbinding sequences from Table 2 in main text (total 150) were combined and the frequency of occurrence (number of selected sequences that contain a particular amino acid at a certain position) was plotted against the amino acid identity. This composite plot is similar to that derived from sequencing of pooled peptides by Edman degradation.

Figure S2: A comparison of the sequence specificities of the 4 SH2 domains of SHP-1 and SHP-2. The size of the letters correlates with the frequency of occurrence of a given amino acid among the selected peptides. 
Sweeney et al.

Table S1. Additional sequences selected against 50 nM SHP-2 C-SH2 domain.

\begin{tabular}{|c|c|c|c|c|}
\hline MAPYAVI & TRPYSII & MKpYASI & YEPYSMI & VRPYSEV \\
\hline IEPYAII & TYPYSII & LLPYAEI & YHPYSVI & VIPYSRV \\
\hline ILPYAII & TVPYSNI & LNPYALI & HYPYSMI & TMpYSAV \\
\hline IKPYAKI & TFPYSSI & LNPYALI & QMpYSTI & TRPYSIV \\
\hline IIPYAQI & TNPYSVI & LSPYALI & LVPYTEI & TYpYSLV \\
\hline IQPYASI & AYPYSTI & IApYALI & TMpYTDI & TEPYSPV \\
\hline IRPYASI & VYPYTAI & IGpYARI & TMpYTGI & TMpYSSV \\
\hline IVPYASI & TIPYTMI & VNPYADI & TNPYTHI & TNPYSYV \\
\hline IYPYASI & TAPYTQI & VRPYADI & TQPYTYI & SYPYSTV \\
\hline IEPYAVI & TYPYTQI & VKpYAFI & SVPYTTI & YSPYSEV \\
\hline INPYAYI & TFPYTRI & VMpYAMI & YIPYTLI & VIpYTHV \\
\hline VQPYAFI & TIPYTSI & VNPYAVI & YEPYTQI & TFPYTDV \\
\hline VTPYAII & TTPYTSI & TSPYAAI & YYPYTTI & YTPYTRV \\
\hline VAPYALI & TSPYTTI & TFPYAFI & HFPYTQI & YNPYTYV \\
\hline VEPYALI & ҮFрYTTI & TAPYAII & MDPYVQI & TEPYVTV \\
\hline VFPYANI & НFРYTTI & TFPYAKI & LHPYVEI & YEPYVFV \\
\hline VGPYAQI & нҮрҮтTI & TEPYAVI & LHPYVSI & YMpYTPT \\
\hline VMPYAQI & VSPYVQI & TKPYAYI & ITpYVSI & VQpYAAI \\
\hline VAPYAVI & THPYVII & SMpYAQI & TDPYVII & VSPYARI \\
\hline VHPYAVI & TNPYVQI & AEPYAEI & THPYVQI & YYPYAHI \\
\hline VLPYAVI & TDPYVVI & AMpYAFI & PWpYVTI & YSPYAII \\
\hline TTPYANI & TEPYVVI & AQPYAVI & AQpYVHI & NRPYAII \\
\hline TSPYAQI & LFPYATV & GLPYAHI & ATpYVVI & VLPYSQI \\
\hline TVPYATI & IAPYAIV & WHPYAEI & YNPYVLI & IHрYTTI \\
\hline TKPYAVI & VSPYATV & WNPYAYI & YEPYVMI & TIPYTMI \\
\hline SGPYAII & TMPYAFV & YAPYADI & NQPYVQI & TIPYTQI \\
\hline SVPYANI & IIPYSQV & FHPYAQI & DApYVSI & TMpYTTI \\
\hline SYPYARI & IQPYSTV & FLPYAVI & EApYVAI & TRPYTVI \\
\hline SNPYAVI & IMPYSVV & HSPYAQI & RApYVVI & TLPYVTI \\
\hline SWPYAVI & VTPYSRV & QPpYATI & YNPYLTI & YTPYVYI \\
\hline PFPYAII & TFPYSVV & NVpYAAI & LLPYATV & VTPYATM \\
\hline PYPYAII & VVPYTAV & NYPYADI & VIPYADV & ITpYTMN \\
\hline AMPYAII & TVPYTQV & NMpYAFI & VLPYAHV & VMpYTAN \\
\hline GHPYAII & IKPYAIL & DKpYAII & VYPYAIV & TQPYVYF \\
\hline GQPYATI & VTPYAQL & DGPYAKI & VIPYALV & TKPYIYE \\
\hline WNPYAII & VIPYATL & MVPYSQI & THPYAQV & IVPYMTE \\
\hline YFPYAHI & TKPYALL & IYPYSPI & TRPYAVV & IHpYMYE \\
\hline YQPYAII & YSPYARL & IEPYSTI & TRPYAVV & SYPYVYY \\
\hline YQPYAKI & TAPYSIL & IAPYSYI & SMpYAVV & YNpYVFY \\
\hline YLPYATI & TMPYTTL & IEPYSYI & AMpYAIV & YApYVYY \\
\hline YEPYAVI & ITрYTTM & TYPYSII & YRPYAQV & IHPYLTY \\
\hline YHPYAVI & VMPYTQM & TYPYSQI & NYPYATV & YRpYMTY \\
\hline YLPYAVI & TYPYAWM & TPPYSVI & IVPYSEV & YDPYMYY \\
\hline VIPYSMI & TVPYLTY & TYPYSVI & IFPYSQV & IVpYITA \\
\hline VFPYSQI & MEPYAEI & SFPYSMI & IIPYSTV & PYPYIFA \\
\hline \multirow[t]{2}{*}{ VVPYSTI } & MMPYAEI & ANpYSTI & VIPYSDV & TVPYLYA \\
\hline & & YAPYSEI & & \\
\hline
\end{tabular}


Sweeney et al.

Table S2. Additional sequences selected against SHP-2 N-SH2 domain.

\begin{tabular}{|c|c|c|c|c|}
\hline Class I & & & & Class III \\
\hline$\overline{\text { IIpYAAI }}$ & IIpYAIL & VNpYMYF & WSPYYLI & ITPYANT \\
\hline IQPYADI & LMpYANL & MHPYVVF & WMpYHMD & ITPYITT \\
\hline IYPYADI & FPpYAVL & YWpYLTF & WSPYTMF & MVpYIVA \\
\hline MRPYAEI & TLPYFTL & YTPYLIY & WIPYTMS & VWpYIVA \\
\hline MVPYAEI & LQPYIIL & ILPYHIY & WSPYENN & MNPYIYA \\
\hline LRpYAHI & LHPYLVL & ITPYITY & WMPYFTT & IHPYLYP \\
\hline IVpYAII & ISPYMVL & IVpYLTY & WMpYKTE & VMpYLYS \\
\hline LLPYAII & LHPYTEL & WNPYMVY & WMpYNTS & LHрYMET \\
\hline YQPYAII & IRPYTIL & LSpYMYY & WMpYRTI & VIPYMST \\
\hline LNPYAKI & WMPYTSL & LHрYTTY & WMpYRTV & LMpYMTS \\
\hline IVPYALI & VVPYTIL & ITPYTYY & WTPYSTR & VWpYMVA \\
\hline LNPYAMI & IWpYVAL & LKpYVYY & WVPYYTT & MVPYMYS \\
\hline YPPYAMI & LNPYVEL & LTPYYYY & WSPYYTT & TMpYMYS \\
\hline VFPYAQI & VNpYVIL & WMpYYGY & WVPYYTT & IMPYTYA \\
\hline VYPYAQI & VIPYAEV & WMPYYQY & WTPYSVK & EMPYTYP \\
\hline YAPYAQI & TLPYAIV & & WMPYNYY & \\
\hline IFPYATI & IWPYATV & Class II & WMPYQYV & Class IV \\
\hline IYPYATI & ISPYAVV & WMpYRGA & WVPYRYT & $\overline{\text { VLPYFAP }}$ \\
\hline LKPYATI & LAPYIQV & WSPYELL & WTPYSYR & ILPYFFP \\
\hline VRPYAVI & IKpYISV & WMpYFIG & & VVPYFIP \\
\hline AYPYAVI & LRPYLQV & WTPYHIM & & LYPYFSP \\
\hline IRPYAYI & LTpYRIV & WSPYKIY & & LMpYLSP \\
\hline ILPYFQI & WTPYSTV & WIPYQIA & & LYPYMPP \\
\hline IQPYIAI & IEPYTAV & WTPYQIE & & MMpYMTP \\
\hline ITPYIDI & VVPYTEV & WTPYQIM & & LRPYMVP \\
\hline INPYINI & IQpYTHV & WMPYQIT & & \\
\hline VQPYLII & IFPYTLV & WMpYS IA & & \\
\hline LHPYLVI & ITpYTLV & WVPYTIA & & \\
\hline LHPYSTI & VKpYTPV & WVPYTIH & & \\
\hline LVPYTAI & VNPYVEV & WTPYTIT & & \\
\hline VKPYTEI & LRPYVFV & WVPYIT & & \\
\hline VQPYTEI & VTpYVQV & WSpYTIV & & \\
\hline LTpYTLI & VVpYVQV & WTPYVIY & & \\
\hline LVPYTQI & LYPYAEM & YVPYYIA & & \\
\hline VFPYTQI & LRPYASM & YIPYYID & & \\
\hline VMpYTQI & TLpYLVM & ITPYYIE & & \\
\hline YLPYTQI & ITpYMAM & AVPYFIA & & \\
\hline VMpYTSI & ITpYRIM & WMPYYID & & \\
\hline YFPYTSI & ITPYSYM & WMpYYIQ & & \\
\hline WTPYTTI & ITpYILN & WMpYYIR & & \\
\hline VVPYTVI & IMpYQIN & WMpYNLA & & \\
\hline IHPYVEI & ITpYVIN & WSPYQLA & & \\
\hline TRPYVEI & ISPYALF & WMpYRLI & & \\
\hline VNPYVEI & LSpYLVF & WTPYSLV & & \\
\hline LHPYVLI & LTpYMSF & WMPYTLE & & \\
\hline LQPYVQI & LQpYMVF & WTPYTLY & & \\
\hline IMpYYGI & TApYMVF & WVPYYLA & & \\
\hline
\end{tabular}


Sweeney et al.

Table S3. Additional SHIP selected peptides from $10 \mathrm{nM}$ screening.

\begin{tabular}{lll} 
AVPYSLL & QLPYTYM & MGPYYFM \\
DGPYSLL & VVPYTYI & QApYYFL \\
YFPYSLV & ARPYVLL & FRPYYFI \\
SYPYSII & YAPYVML & GGPYYFI \\
FQPYSVM & MGPYVYM & DGPYYFV \\
AMPYSVM & KGPYVYM & MYPYYYM \\
PYPYSFA & PFPYYLL & MQPYYYM \\
WYPYSFI & QGPYYLL & QAPYYYI \\
PTPYSFL & WAPYYLV & ATPYYYI \\
LNPYTLL & GTPYYLV & YLPYYYI \\
VLPYTLL & YFPYYLA & PMPYYYI \\
SSPYTLL & LTPYYMM & QVPYYYV \\
ANPYTLM & PQPYYMI & FYPYFYA \\
NLPYTLM & PFPYYMI & YTPYFYV \\
PFPYTML & KGPYYVM & TVPYALM \\
\hline
\end{tabular}




\section{Sweeney et al.}

Table S4. Additional SHP-1 and SHP-2 interacting proteins.

\begin{tabular}{|c|c|c|}
\hline Protein & Known or putative Binding Motif(s) & Ref. \\
\hline Bradykinin Receptor (B2R) & LVpYVIV & 1 \\
\hline $\mathrm{Cas}-\mathrm{L}^{\mathrm{b}}$ & YDPYVHL & 2 \\
\hline Catenin ${ }^{a, b}$ & RGpYELL (?), RIpYISL (?) & 3,4 \\
\hline $\mathrm{CD}^{\mathrm{a}}$ & LApYKKL & 5 \\
\hline $\mathrm{CD} 72^{\mathrm{a}}$ & ITpYADL & 6,7 \\
\hline $\mathrm{C}-\mathrm{Kit}^{\mathrm{a}, \mathrm{b}}$ & YVpYIDP $($ SHP-1), NNpYVYI $($ SHP -2$)$ & 8,9 \\
\hline $\operatorname{CTLA}-4^{a, b}$ & QPPYFIP & 10 \\
\hline Death receptor ${ }^{a, b, c}$ & AQpYSML & 11 \\
\hline EGFR $^{a}$ & AEpYLRV & 12 \\
\hline EphA2 kinase & AGpYTAI (?), IApYSLL (?) & 13 \\
\hline Epo receptor ${ }^{a, b, c}$ & LKPYLYL $($ SHP-1), FEPYTIL (SHP-2/SHIP $)$ & $14-16$ \\
\hline E-selectin & GSPYQKP & 17 \\
\hline Focal adhesion kinase 2 (Pyk2) $^{D}$ & LVpYLNV & 18 \\
\hline $\mathrm{FRS}^{\mathrm{b}}$ & LNpYIQV, ELPYAVI & 19 \\
\hline $\mathrm{Gab}-1^{\mathrm{b}}$ & VEpYLDL, VDPYVVV & 20 \\
\hline$G a b-2^{a, b}$ & VDPYLAL, VDPYVQV & 21,22 \\
\hline $\mathrm{Gab}-3^{\mathrm{b}}$ & LDPYLAL, VDpYVQV & 23 \\
\hline$I G F-1 R^{b}$ & QPPYAHM & 24 \\
\hline IL-3 receptor ${ }^{a, b}$ & LEpYLCL & 25 \\
\hline IL-4 receptor ${ }^{a, b}$ & IVpYSAL & 26 \\
\hline IL-6 receptor ${ }^{b}$ & VQpYSTV & 27 \\
\hline $\begin{array}{l}\text { Immunoglobulin-like transcript } \\
2(\mathrm{LIR}-1)^{a}\end{array}$ & VTPYAQL, SIPYATL & 28 \\
\hline Insulin receptor & IPPYTHM & 29 \\
\hline Insulin receptor substrate-1 ${ }^{b}$ & LNpYIDL, SApYASI & 30 \\
\hline Insulin receptor substrate- $2^{b}$ & LNpYIAI, NTpYASI & 31 \\
\hline Lectin-like immunoreceptor ${ }^{a}$ & ITpYAEV & 32 \\
\hline Leptin receptor ${ }^{b}$ & VKpYATL & 33 \\
\hline $\operatorname{LIFR}^{\mathrm{b}}$ & VIpYIDV & 34 \\
\hline $\mathrm{PD}-1^{\mathrm{a}}$ & TEPYATI & 35,36 \\
\hline PDGFR & VLPYATV & 37 \\
\hline Prolactin receptor ${ }^{b}$ & LDpYLDP & 38 \\
\hline $\operatorname{Ros}^{2}$ & LNpYMVL & 39 \\
\hline $\begin{array}{l}\text { SHP2-interacting transmembrane } \\
\text { adaptor protein }(\mathrm{SIT})^{b}\end{array}$ & VKpYSEV, MCpYTSL (?), ELpYASV (?) & 40 \\
\hline SIGLEC $-7^{\frac{1}{2}}$ & IQpYAPL, NEpYSEI & 41 \\
\hline SIGLEC-1 $0^{a, b}$ & LDPYINV, LHpYATL, ADpYAEV & 42,43 \\
\hline Somatostatin receptor $2^{a, b}$ & LCPYLFI, ILPYAFL & 44,45 \\
\hline STAT3 $^{b}$ & LVpYLYP (?) & 46 \\
\hline STAT5 $5^{a, b}$ & LNpYLIY (?) & 47,48 \\
\hline Tek receptor tyrosine kinase & TIPYPVL, FTpYAGI & 49 \\
\hline TREM-like transcript $1($ TLT-1) & VTPYATI & 50 \\
\hline Tpr-Met oncoprotein ${ }^{b}$ & ATpYVNV & 51 \\
\hline $\begin{array}{l}\text { Vascular endothelial growth } \\
\text { factor receptor }-1^{b}\end{array}$ & VRPYVNA & 52 \\
\hline
\end{tabular}

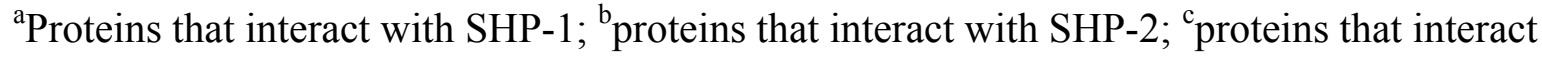
with SHIP. Questions marks indicate that the role of the motif in binding SHP-1, SHP-2, and/or SHIP has not been confirmed. 
Figure S1: Composite plot of all four classes of SHP-2 N-SH2 domain-binding sequences

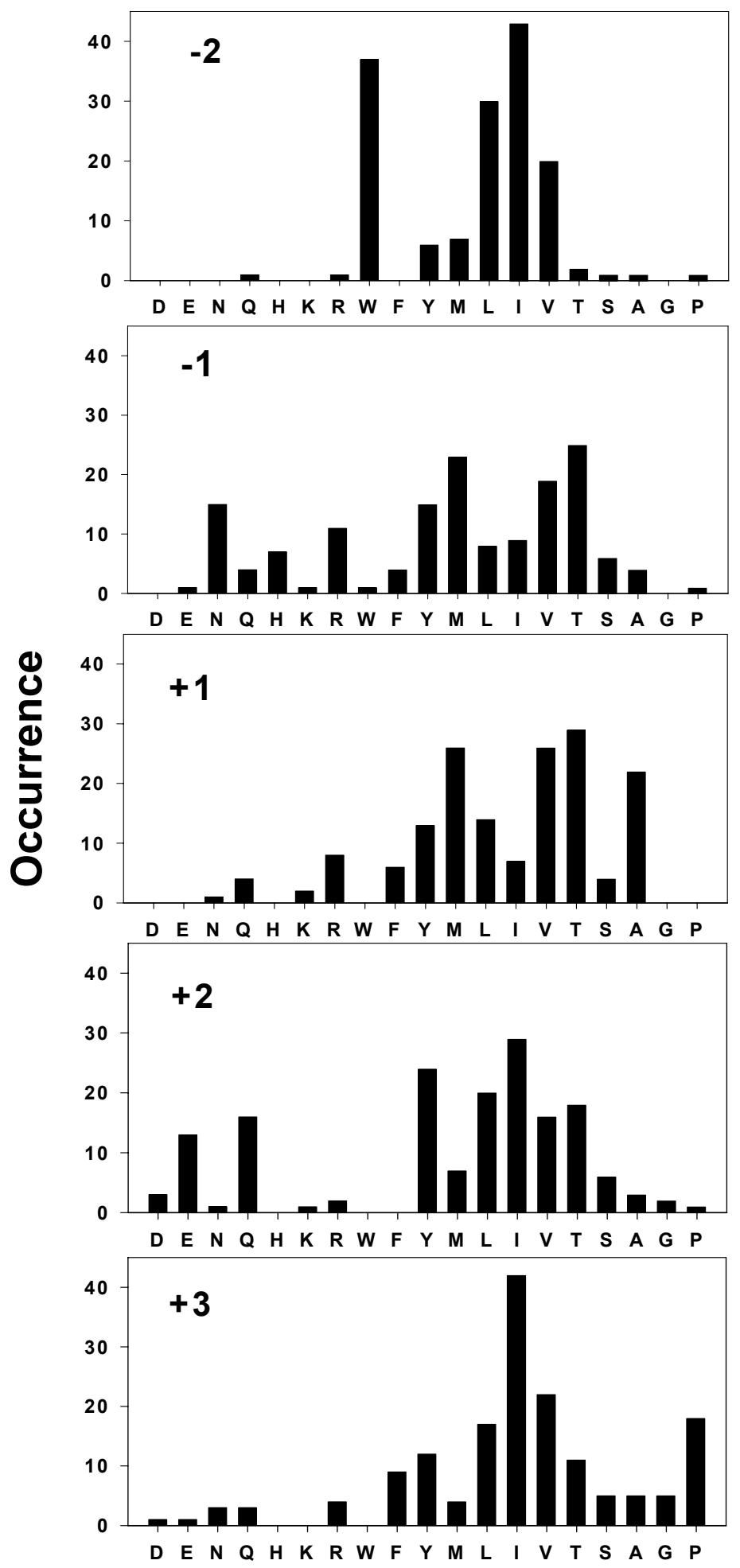




\section{Figure S2. Comparison of SHP-1 and SHP-2 SH2 Domains}

\section{SHP-1}

C-SH2

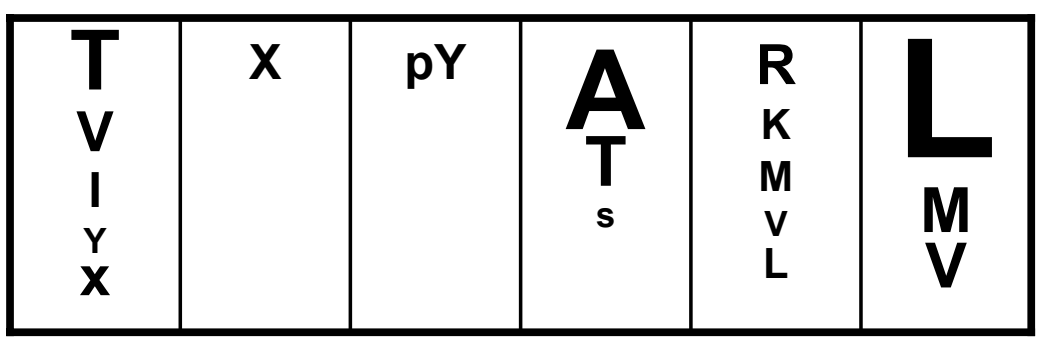

N-SH2

\begin{tabular}{|c|c|c|c|c|c|}
\hline-2 & -1 & $\mathrm{pY}$ & +1 & +2 & +3 \\
\hline $\mathrm{L}$ & $\mathrm{Y} / \mathrm{H}$ & & $\mathbf{A}$ & $\mathrm{X}$ & \\
$\mathrm{I}$ & $\mathrm{N}$ & & $\mathrm{V}$ & & $\mathbf{F}$ \\
& $\mathrm{X}$ & & & & $\mathrm{F}$ \\
\hline $\mathrm{L}$ & $\mathrm{Y} / \mathrm{H}$ & $\mathrm{pY}$ & $\mathrm{M}$ & $\mathrm{X}$ & $\mathbf{F}$ \\
$\mathrm{I} / \mathrm{V}$ & $\mathrm{R} / \mathrm{K}$ & & $\mathbf{Q}$ & & $\mathrm{M}$ \\
$\mathrm{M}$ & $\mathrm{N}$ & & $\mathrm{F}$ & & $\mathrm{L}$ \\
\hline
\end{tabular}

Note: The font size reflects the frequency at which a particular amino acid is selected, with larger font size representing higher frequency.
SHP-2

\begin{tabular}{|c|c|c|c|c|c|}
\hline $\mathbf{T}$ & $\mathrm{X}$ & $\mathrm{pY}$ & $\mathbf{A}$ & $\mathrm{I}$ & $\mathbf{V}$ \\
$\mathbf{V}$ & & & $\mathbf{V}$ & \\
$\mathbf{I}$ & & & $\mathbf{S}$ & $\mathbf{T}$ & $\mathbf{V}$ \\
$\mathrm{Y}$ & & & $\mathbf{T}$ & $\mathbf{Q}$ & $\mathrm{L}$ \\
\hline
\end{tabular}

\begin{tabular}{|c|c|c|c|c|c|}
\hline-2 & -1 & pY & +1 & +2 & +3 \\
\hline $\begin{array}{c}/ L \\
V \\
M\end{array}$ & $\begin{array}{l}T / V \\
N \\
M \\
X\end{array}$ & & $\begin{array}{c}\text { T/V } \\
\text { A }\end{array}$ & $\mathbf{x}$ & $\prod_{\mathrm{V} / \mathrm{L}}$ \\
\hline $\mathbf{W}$ & $\begin{array}{c}\mathbf{M} \\
\mathbf{v}\end{array}$ & py & $\begin{array}{c}\mathbf{R} \\
\mathbf{Y} \\
\mathbf{Q} / \mathrm{S} / \mathrm{T} / \mathrm{V} \\
\mathbf{K}\end{array}$ & $\mathbf{L}$ & $\bar{x}$ \\
\hline $\mathrm{I}_{\mathrm{L}}^{\mathrm{I}}$ & $x$ & py & $\underset{T}{L / M}$ & $Y$ & $\begin{array}{l}\mathrm{A} / \mathrm{P} / \mathrm{T} \\
\mathrm{S} / \mathrm{G}\end{array}$ \\
\hline $\mathrm{I} / \mathrm{V} / \mathrm{L}$ & $x$ & pY & $\mathrm{M} / \mathrm{F}$ & $X$ & $\mathbf{P}$ \\
\hline
\end{tabular}




\section{References}

1. Duchene, J. et al. A novel protein-protein interaction between a G protein-coupled receptor and the phosphatase SHP-2 is involved in Bradykinin-induced inhibition of cell proliferation. J. Biol. Chem. 277, 40375-40383 (2002).

2. Minegishi, M., Tachibana, K., Sato, T., Iwata, S., Nojima, Y., and Morimoto, C. Structure and function of Cas-L, a 105-kD Crk-associated substrate-related protein that is involved in $\beta 1$ integrin-mediated signaling in lymphocytes. J. Exp. Med. 184, 1365-1375 (1996).

3. Keilhack, H. et al. The protein-tyrosine phosphatase SHP-1 binds to and dephosphorylates p120 catenin. J. Biol. Chem. 275, 26376-26384 (2000).

4. Ukropec, J. A., Hollinger, M. K., Salva, S. M., and Woolkalis, M. J. SHP2 associates with VE-cadherin complexes in human endothelial cells is regulated by thrombin. $J$. Biol. Chem. 275, 5983-5986 (2000).

5. Perez-Villar, J. J., Whitney, G. S., Bowen, M. A., Hewgill, D. H., Aruffo, A. A., and Kanner, S. B. CD5 negatively regulates the T-cell antigen receptor signal transduction pathway: Involvement of SH2-containing phosphotyrosine phosphatase SHP-1. Mol. Cell. Biol. 19, 2903-2912 (1999).

6. $\mathrm{Wu}, \mathrm{Y}$. et al. The B-cell transmembrane protein CD72 binds to and is an in vivo substrate of the protein tyrosine phosphatase SHP-1. Curr. Biol. 8, 1009-1017 (1998).

7. Adachi, T., Flaswinkel, H., Yakura, H., Reth, M., and Tsubata, T. Cutting edge: The B cell surface protein CD72 recruits the tyrosine phosphatase SHP-1 upon tyrosine phosphorylation. J. Immunol. 160, $4662-4665$ (1998).

8. Tauchi, T. et al. The ubiquitously expressed Syp phosphatase interacts with c-kit and Grb2 in hematopoietic cells. J. Biol. Chem. 269, 25206-25211 (1994).

9. Kozlowski, M., Larose, L., Lee, F., Le, D. M., Rottapel, R., and Siminovitch, K. A. SHP-1 binds and negatively modulates the c-Kit receptor by interaction with tyrosine 569 in the c-Kit juxtamembrane domain. Mol. Cell. Biol. 18, 2089-2099 (1998).

10. Guntermann, C., and Alexander, D. R. CTLA-4 suppresses proximal TCR signaling in resting human CD4+ T cells by inhibiting ZAP-70 Tyr-319 phosphorylation: A potential role for tyrosine phosphatases. J. Immunol. 168, 4420-4429 (2002).

11. Daigle, I., Yousefi, S., Colonna, M., Green, D. R., and Simon, H.-U. Death receptors bind SHP-1 and block cytokine-induced anti-apoptotic signaling in neutrophils. Nature Med. 8, 61-67 (2002).

12. Keilhack, H. et al. Phosphotyrosine 1173 mediates binding of the protein-tyrosine phosphatase SHP-1 to the epidermal growth factor receptor and attenuation of receptor signaling. J. Biol. Chem. 273, 24839-24846 (1998).

13. Miao, H., Burnett, E., Kinch, M., Simon, E., and Wang, B. Activation of EphA2 kinase suppresses integrin function and causes focal-adhesion-kinase dephosphorylation. Nat. Cell Biol. 2, 62-69 (2000).

14. Klingmuller, U., Lorenz, U., Cantley, L. C., Neel, B. G., and Lodish, H. F. Specific recruitment of SH-PTP1 to the erythropoietin receptor causes inactivation of JAK2 and termination of proliferative signals. Cell 80, 1445 (1993).

15. Tauchi, T. et al. Tyrosine 425 within the activated erythropoietin receptor binds Syp, reduces the erythropoietin required for Syp tyrosine phosphorylation, and promotes mitogenesis. Blood 87, 4495-4501 (1996). 
16. Mason, J. M., Beattie, B. K., Liu, Q., Dumont, D. J., and Barber, D. L. The SH2 inositol 5-phosphatase Ship1 is recruited in an SH2-depedent manner to the erythropoietin receptor. J. Biol. Chem. 275, 4398-4406 (2000).

17. Hu, Y., Szente, B., Kiely, J.-M., and Gimbrone, M. A. Jr. Molecular events in transmembrane signaling via E-selectin. J. Biol. Chem. 276, 48549-48553 (2001).

18. Chauhan D, Pandey P, Hideshima T, Treon S, Raje N, Davies FE, Shima Y, Tai YT, Rosen S, Avraham S, Kharbanda S, Anderson KC. SHP2 mediates the protective effect of interleukin-6 against dexamethasone-induced apoptosis in multiple myeloma cells. J Biol Chem. 275, 27845-50 (2000).

19. Hadari, Y. R.; Kouhara, H.; Lax, I.; Schlessinger, J. Binding of Shp2 tyrosine phosphatase to FRS2 is essential for fibroblast growth factor-induced PC12 cell differentiation. Mol. Cell. Biol. 18, 3966-3973 (1998).

20. Cunnick, J. M., Mei, L., Doupnik, C. A., and Wu, J. Phosphotyrosines 627 and 659 of Gab1 constitutes a bisphosphoryl tyrosine-based activation motif (BTAM) conferring binding and activation of SHP-2. J. Biol. Chem. 276, 24380-24387 (2001).

21. Yamasaki, S. et al. Docking protein Gab2 is phosphorylated by ZAP-70 and negatively regulates $\mathrm{T}$ cell receptor signaling by recruitment of inhibitory molecules. J. Biol. Chem. 276, 45175-45183 (2001).

22. Yu, W.-M., Hawley, T. S., Hawley, R. G., and Qu, C.-K. Role of the docking protein Gab2 in $\beta 1$-integrin signaling pathway-mediated hematopoietic cell adhesion and migration. Blood 99, 2351-2359 (2002).

23. Wolf, I. Et al. Gab3, a new DOS/Gab family member, facilitates macrophage differentiation. Mol. Cell. Biol. 22, 231-244 (2002).

24. Seely, B. L. et al. Localization of the insulin-like growth factor I receptor binding sites for the SH2 domain proteins p85, Syp, and GTPase activating protein. J. Biol. Chem. 270, 19151-19157 (1995).

25. Bone, H., Dechert, U., Jirik, F., Schrader, J. W., and Welham, M. J. SHP1 and SHP2 protein-tyrosine phosphatases associate with $\beta \mathrm{c}$ after interleukine-3-induced receptor tyrosine phosphorylation. J. Biol. Chem. 272, 14470-14476 (1997).

26. Kashiwada, M., Giallourakis, C. C., Pan, P.-Y., and Rothman, P. B. Immunoreceptor tyrosine-based motif of the IL-4 receptor associates with SH2-containing phosphatases and regulates IL-4-induced proliferation. J. Immunol. 167, 6382-6387 (2001).

27. Kim, H., and Baumann, H. Dual signaling role of the protein tyrosine phosphatase SHP-2 in regulating expression of acute-phase plasma proteins by interleukine-6 cytokine receptors in hepatic cells. Mol. Cell. Biol. 19, 5326-5338 (1999).

28. Bellon, T.; Kitzig, F.; Sayos, J.; Lopez-Botet, M. Mutational analysis of immunoreceptor tyrosine-based inhibition motifs of the Ig-like transcript 2 (CD85j) leukocyte receptor. J. Immunol. 168, 3351-3359 (2002).

29. Staubs, P. A., Reichart, D. R., Saltiel, A. R., Milarski, K. L., Maegawa, H., Berhanu, P., Olefsky, J. M., and Seely, B. L. Localization of the insulin receptor binding sites for the SH2 domain proteins p85, Syp, and GAP. J. Biol. Chem. 269, 27186-27192 (1994).

30. Myers, M. G. Jr., Mendez, R., Shi, P., Pierce, J. H., Rhoads, R., and White, M. F. The COOH-terminal tyrosine phosphorylation sites on IRS-1 bind SHP-2 and negatively regulate insulin signaling. J. Biol. Chem. 273, 26908-26914 (1998). 
31. Argetsinger, L. S., Norstedt, G., Billestrup, N., White, M. F., and Carter-Su, C. Growth hormone, interferon-g, and leukemia inhibitory factor utilize insulin receptor substrate-2 in intracellular signaling. J. Biol. Chem. 271, 29415-29421 (1996).

32. Huang, X., Yuan, Z., Chen, G., Zhang, M., Zhang, W., Yu, Y., and Cao, X. Cloning and characterization of a novel ITIM containing lectin-like immunoreceptor LLIR and its two transmembrane region deletion variants. Biochem. Biophys. Res. Comm. 281, 131-140 (2001).

33. Bjorbaek, C., Lavery, H. J., Bates, S. H., Olson, R. K., Davis, S. M., Flier, J. S., and Myers, M. G. Jr. SOCS3 mediates feedback inhibition of the leptin receptor via Tyr985. J. Biol. Chem. 275, 40649-40657 (2000).

34. Clahsen, T., Lehmann, U., Stross, C., Hermanns, H. M., Volkmer-Engert, R., Schneider-Mergener, J., Heinrich, P. C., and Schaper, F. The tyrosine 974 within the LIF-R-chain of the gp130/LIF-R heteromeric receptor complex mediates negative regulation of LIF signaling. Cell. Signal. 17, 559-569 (2005).

35. Okazaki, T., Maeda, A., Nishimura, H., Kurosaki, T., and Honjo, T. PD-1 immunoreceptor inhibits B cell receptor-mediated signaling by recruiting src homology 2-domain-containing tyrosine phosphatase 2 to phosphotyrosine. Proc. Natl. Acad. Sci. U.S.A. 98, 13866-13871 (2001).

36. Sheppard, K.-A., Fitz, L. J., Lee, J. M., Benarder, C., George, J. A., Wooters, J., Qiu, Y., Jussif, J. M., Carter, L. L., Wood, C. R., and Chaudhary, D. PD-1 inhibits T-cell receptor induced phosphorylation of the ZAP70/CD3 $\zeta$ signalosome and downstream signaling to PKC $\theta$. FEBS Lett. 574, 37-41 (2004).

37. Baznet, C. E., Gelderloos, J. A., and Kazlauskas, A. Phosphorylation of tyrosine 720 in the platelet-derived growth factor $\alpha$ receptor is required for binding of Grb2 and SHP-2 but not for activation of Ras or cell proliferation. Mol. Cell. Biol. 16, 69266936 (1996).

38. Ali, S., and Ali, S. Recruitment of the protein-tyrosine phosphatase SHP-2 to the Cterminal tyrosine of the prolactin receptor and to the adaptor protein Gab2. J. Biol. Chem. 275, 39073-39080 (2000).

39. Keilhack, H. et al. Negative regulation of Ros receptor tyrosine kinase signaling: An epithelial function of the SH2 domain protein tyrosine phosphatase SHP-1. J. Cell Biol. 152, 325-334 (2001).

40. Marie-Cardine, A., Kirchgessner, H., Bruyns, E., Shevchenko, A., Mann, M., Autschbach, F., Ratnofsky, S., Meuer, S., and Schraven, B. SHP-2-interacting transmembrane adaptor protein (SIT), a novel disulfide-linked dimer regulating human T cell activation. J. Exp. Med. 189, 1181-1194 (1999).

41. Falco, M., Biassoni, R., Bottino, C., Vitale, M., Sivori, S., Augugliaro, R., Moretta, L., and Moretta, A. Identification and molecular cloning of p75/AIRM1, a novel member of the sialoadhesion family that functions as an inhibitory receptor in human killer cells. J. Exp. Med. 190, 793-801 (1999).

42. Kitzig, F., Martinez-Barriocanal, A., Lopez-Botet, M., and Sayos, J. Cloning of two new splice variants of Siglec-10 and mapping of the interaction between Siglec-10 and SHP-1. Biochem. Biophys. Res. Comm. 296, 355-362 (2002).

43. Whitney, G., Wang, S., Chang, H., Cheng, K.-Y., Lu, P., Zhou, X. D., Yang, W.-P., McKinnon, M., and Longphre, M. A new siglec family member, siglec-10, is 
expressed in cells of the immune system and has signaling properties similar to CD33. Eur. J. Biochem. 268, 6083-6096 (2001).

44. Lopez, F., Esteve, J.-P., Buscail, L. et al. The tyrosine phosphatase SHP-1 associates with the sst2 somatostatin receptor and is an essential component of sst2-mediated inhibitory growth signaling. J. Biol. Chem. 272, 24448-24454 (1997).

45. Ferjoux, G. et al. Critical role of Src and SHP-2 in sst2 somatostatin receptormediated activation of SHP-1 and inhibition of cell proliferation. Mol. Biol. Cell 14, 3911-3928 (2003).

46. Gunaje, J. J., and Bhat, G. J. Involvement of tyrosine phosphatase PTP1D in the inhibition of interleukine-6-induced Stat 3 signaling by $\alpha$-thrombin. Biochem. Biophys. Res. Commun. 288, 252-257 (2001).

47. Ram, P. A., and Waxman, D. J. Interaction of growth hormone-activated STATs with SH2-containing phosphotyrosine phosphatase SHP-1 and nuclear JAK2 tyrosine kinase. J. Biol. Chem. 272, 17694-17702 (1997).

48. Chughtai, N., Schimchowitsch, S., Lebrun, J.-J., and Ali, S. Prolactin induces SHP-2 association with Stat5, nuclear translocation, and binding to the $\beta$-casein gene promoter in mammary cells. J. Biol. Chem. 277, 31107-31114 (2002).

49. Jones, N., Master, Z., Jones, J., Bouchard, D., Gunji, Y., Sasaki, H., Daly, R., Alito, K., and Dumont, D. J. Identification of Tek/Tie2 binding sites. J. Biol. Chem. 274, 30896-30905 (1999).

50. Barrow, A. D. et al. Cutting edge: TREM-like transcript-1, a platelet immunoreceptor tyrosine-based inhibition motif encoding costimulatory immunoreceptor that enhances, rather than inhibits, calcium signaling via SHP-2. J. Immunol. 172, 5838$5842(2004)$.

51. Fixman, E. D. et al. Pathways downstream of She and Grb2 are required for cell transformation by the Tpr-Met oncoprotein. J. Biol. Chem. 271, 13116-13122 (1996).

52. Ito, N., Wernstedt, C., Engstrom, U., and Claesson-Welsh, L. Identification of vascular endothelial growth factor receptor-1 tyrosine phosphorylation sites and binding of SH2 domain-containing molecules. J. Biol. Chem. 273, 23410-23418 (1998). 